DOI: https://doi.org/10.34069/AI/2021.44.08.2

How to Cite:

Baliun, O., Kashpur, A., Fisenko, T., Segol, R., \& Husak, O. (2021). TRuSt method: Mediation of stakeholders for improvement of urban development strategies. Amazonia Investiga, 10(44), 18-27. https://doi.org/10.34069/AI/2021.44.08.2

\title{
TRuSt method: Mediation of stakeholders for improvement of urban development strategies
}

\section{МЕТОДИКА TRuSt: МЕДІАЦІЯ СТЕЙКХОЛДЕРІВ ДЛЯ ПІДВИЩЕННЯ ЕФЕКТИВНОСТІ СТРАТЕГІЙ РОЗВИТКУ МІСТ}

Received: June 26, 2021

\begin{abstract}
The purpose of this study is to determine the factors that influence the effectiveness of applying the mediation techniques of stakeholder groups for strategic urban and territorial development exemplified by practical implementation of Triad Retrospective Scripting method in Ukraine. As part of the study, the authors have used the general-scientific and specialized methods of research: a) general theoretical methods such as analysis, synthesis and comparing; b) sociological research methods such as surveys, in-depth interviews, expert studies, roundtable discussions; c) systematic methods of analysis on this subject matter and a case-study method. In the course of the research, the authors have analysed and described the Triad Retrospective Scripting method based on a project-scenario approach. It is on the basis of this technique the practical approbation has been carried out and it has shown that its application makes it possible to significantly reduce the level of negative feedback and to involve the
\end{abstract}

Accepted: August 10, 2021

\author{
Written by: \\ Baliun Oksana \\ https://orcid.org/0000-0002-7676-9049 \\ Kashpur Andrii \\ https://orcid.org/0000-0002-5954-9060 \\ Fisenko Tetiana ${ }^{8}$ \\ https://orcid.org/0000-0003-1837-0117 \\ Segol Radmila \\ https://orcid.org/0000-0002-3231-531X \\ Husak Olviia ${ }^{10}$ \\ https://orcid.org/0000-0002-7255-6492
}

\footnotetext{
${ }^{6} \mathrm{PhD}$, Associate professor of the Department of Publishing and Editing National Technical University of Ukraine Igor Sikorsky Kyiv Polytechnic Institute, Ukraine.

${ }^{7} \mathrm{PhD}$, head of the Reputation Lab ${ }^{\mathrm{TM}}$ Research Centre, Ukraine.

${ }^{8} \mathrm{PhD}$, Associate professor of the Department of Publishing and Editing National Technical University of Ukraine Igor Sikorsky Kyiv Polytechnic Institute, Ukraine.

${ }^{9} \mathrm{PhD}$, Associate professor of the Department of Publishing and Editing National Technical University of Ukraine Igor Sikorsky Kyiv Polytechnic Institute, Ukraine.

${ }^{10} \mathrm{PhD}$, Associate professor of the Department of Publishing and Editing National Technical University of Ukraine Igor Sikorsky Kyiv Polytechnic Institute, Ukraine.
}

\begin{abstract}
Анотація
Розвиток комунікаційних та інформаційних технологій став одним 3 ключових драйверів трансформацій систем врядування, як на рівні (local government) - зростаючі комунікаційні можливості людей збільшують їх вплив одне на до виникнення багатовегторних гомуніканій, в яких беруть активну участь (є джерелами інформаційного впливу та генераторами контенту) групи з різними інтересами та цілями. факторів впливу на ефективність застосування методик медіації стейкхолдерних груп стратегічного розвитку міст та територій, на прикладі практичного застосування в Україні методики Triad Retrospective Scripting. Під час дослідження автори застосували загальнонаукові та спеціальні методи наукового пізнання: $\quad$ a) загальнотеоретичні методи аналіз, синтез та порівняння; б) методи соціологічних досліджень такі як опитування, глибинні інтерв'ю, експертні дослідження,
\end{abstract}




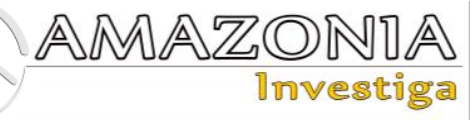

stakeholder groups, who are in opposition to each other otherwise, in collaborative work. The recommendations for minimizing the negative effects of key factors that influence the mediation of stakeholder groups for urban and territorial development have been formulated as part of this study.

Key Words: public and private partner, public decision-making, city development, territorial marketing, TRuSt method.

круглі столи; с) систематичні методи аналізу досліджуваної інформації та a case-study method. В процесі дослідження авторами проаналізовано, описано методику Triad Retrospective Scripting, яка базується на проєктно-сценарному підході. На основі цієї методики автори провели практичну апробацію, яка продемонструвала, що iï застосування дозволяє суттєво зменшити рівень негативних відгуків та поєднати у спільній роботі стейкхолдерні групи, які за інших умов знаходяться в опозиції одне до одного. В рамках дослідження було сформульовано рекомендації стосовно мінімізації негативних наслідків ключових факторів впливу на медіацію стейкхолдерних груп розвитку міст та територій.

Ключові слова: державно-громадянське партнерство, публічне громадське обговорення, розвиток міста, територіальний маркетинг, метод TRuSt.

\section{Introduction}

The rapid growth of communications capabilities of individuals and communities has led to the fact that the media resources of government, especially a local one, are significantly inferior to the resources available to the citizens. As a consequence, the development strategies that are formulated by the authorities are becoming more and more vulnerable with respect to information, that is, they are exposed to the active information pressure and public criticism both at their own discretion and due to the influence of political opponents of the current government.

This issue has become particularly acute for Ukraine, which has set a course for decentralization, the development of local communities and government at the national level since 2015. At the same time, there is in fact no social experience or relevant tools for building the dialogue systems between different pressure groups among political parties, businesses and members of the general public in Ukraine.

The experience in elaborating and implementing the effective urban and territorial development strategies is virtually non-existent in Ukraine as well. Most of them have been developed within the framework and with the resources of the EU Technical Assistance Program and are rather formal, have a low efficiency level of implementation in practice and correspondingly low or undefined performance indicators.

As a result, the strategy that is developed by local governments immediately has become the target of criticism, the media volume of which far exceeds the positive and constructive feedback. Thus, a negative image, which hinders or even cancels the strategy implementation, is created in the information space.

The purpose of this study is to identify the factors that influence the effectiveness of applying the mediation techniques of stakeholder groups for strategic urban and territorial development by the example of practical implementation of TRuSt (Triad Retrospective Scripting) method in Ukraine. In the course of the research, the following tasks had been accomplished: the problem state of the emergence of information counteraction (criticism) to the elaborating and implementing territorial development strategies in Ukraine has been analysed; the theoretical basis and practice of application of the technique developed in Ukraine have been studied; the recommendations for minimizing the negative consequences of key factors that influence the mediation of stakeholder groups for urban and territorial development have been formulated.

\section{Literature review}

The problem of methodology for territory management, its communication and information component in the context of the territorial development strategy elaboration is becoming 
essential, particularly in the research of scientists. The international research experiences are presented in scientific works of M. Jouini, J. Burte, Y. Biard, N. Benaissa, H. Amara, C. Sinfort (Jouini et al., 2019). For example, the studies demonstrate the application of life cycle assessment technique (LCA) within Tunisian territory and indicate that integrating stakeholders in LCA supports public decisionmaking.

An interesting approach to the problem and the description of a decision-making model based on the viable system approach (VsA) were proposed by C.Simone, S.Barile, M.Calabrese (Simone et al., 2018). In the research work which is called «Problems and Prospects in Community Engagement in Urban Planning and DecisionMaking: Three Case Studies from the Australian Capital Territory», Australian scientists draw attention to the issue of insufficient citizen involvement in urban planning processes participation. The authors are focused on the study of the causes of this phenomenon (Stewart \& Lithgow, 2015). A wide range of issues related to our study was raised in the scientific article called «Territory Planning and Management: the Theory Debate in Brazil and a Prospect of Practice According to Theoretical Contributions on Territorial Governance» (Dallabrida, 2015).

In the research work which is called «Monitoring of Social Reactions to Support Decision Making on Issues of Urban Territory Management» the authors pay attention to the information and the technical component of the problem of information collection and processing. In particular, the process of analysis of citizens preferences for decision support in the management of development problems in urban areas is described (Ustugova et al., 2016).

In part, the issue of improving the effectiveness of strategies for the development of cities and territories have been also investigated in the scientific papers of the following scientists: A. Vergara-Romero, \& R. Sorhegui-Ortega (Vergara-Romero, \& Sorhegui-Ortega 2020), O. Ugurchiev, S.-A. Dovtaev, L. Tochieva, A. Sabanchiev, \& A. Misakov (Ugurchiev et al., 2019), S. Golikov, O. Korneyko, \& E. Krasova, (Golikov, Korneyko, \& Krasova, 2018), T. Kolomoiets, N. Galitsina, A. Sharaia, V. Kachuriner, \& O. Danylenko (Kolomoiets et al., 2021).

However, according to the authors of the study, these examples do not fully describe the problematics and the opportunities for interaction of different stakeholder groups and methods of formation and mediation of dialogue spaces, which have a significant impact on the effectiveness of elaborating and implementing urban and territorial development strategies.

\section{Methodology}

The general and specialized methods of scientific knowledge were used in this study. In particular, such general theoretical methods such as analysis, synthesis and comparing were applied to analyse the identification of the main factors that lead to the formation of public distrust in urban development strategies. The sociological research methods such as surveys, in-depth interviews, expert studies, roundtable discussions were used in the practical testing of TRuSt method, especially in order to identify the effects of changes in the level of involvement of public and various stakeholder groups in the process of developing urban strategy. Moreover, 21 local government officials were surveyed through face-to-face interviews for this study. The authors used the systematic methods of analysis on this subject matter in order to study the existing theoretical developments and the practice of their application in Ukraine. Finally, the practical testing of the TRuSt method was performed by applying a case-study method.

\section{Results and Discussion}

According to the survey «Participatory Democracy and Reasonable Decisions at the Local Level in Ukraine» (that was conducted in 2018 and implemented by the Association of Ukrainian Cities and the Norwegian Association of Local and Regional Authorities in cooperation with the Norwegian Institute for Urban and Regional Research funded by the Norwegian Ministry of Foreign Affairs), the residents of Ukrainian cities and united territorial communities have a low level of awareness about decentralization reform. Around $37 \%$ of respondents from urban areas believe that the decentralization reform has affected the development of their locality. As far as experts are concerned, this figure rises to $60 \%$. Only $32 \%$ of urban residents consider that the promises of local authorities are worthy of trust. Approximately $37 \%$ of them agree that the local authorities of their cities listen to the opinion of citizens, whereas 54\% - totally deny it (Association of Ukrainian Cities, 2017).

Similar numbers are shown by «Active Group» company in their «All-Ukrainian Omnibus» research on the level of credibility in the central 


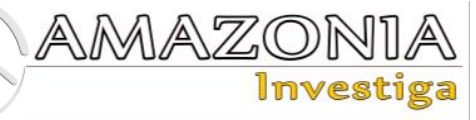

and local authorities and the results of local elections among Ukrainian people. Only 33,6\% of urban residents positively assessed the level of their trust in the mayor of the city. In fact, the average weighted score of the urban residents' trust in the mayor was 3,09 on a scale from one to five. Only $29,4 \%$ of respondents expect the significant positive changes as a result of the 2020 local elections (Active Group, 2020).

Around $32 \%$ of Ukrainians do not trust anyone in matters of politics. According to the study entitled «Decentralization and Local Government Reform: the Results of the Fifth Wave of the All-Ukrainian Sociological Survey», which was conducted during AugustSeptember 2020 by the «Social Indicators» Centre at the request of «Decentralization and Local Government Reform in Ukraine» Program of the Council of Europe, $43 \%$ and $34 \%$ of Ukrainians do not trust politicians and the government, while $28,5 \%$ generally consider that nothing depends on them (Council of Europe, 2020).

The analysis of these studies allowed us to assume and conclude that these three different studies actually lead to the same end result: a significant part of Ukrainians do not trust the authorities (in this case - the local ones) and do not expect that the significant positive changes can be achieved. The reasons are beyond the scope of this study, but it is important that they provide a basis for a substantial consequence, namely the high level of skepticism about the local government initiatives, which are most notably manifested in criticism of strategies and plans for urban and territorial development. This skepticism creates a problem that is about the reduction in effectiveness of the implementation of these strategies, which is already visible during their development.

In addition, according to the authors of this study, the following factors influence the decline in efficiency:

- The real motives for creating a strategy.

- The format of work on the strategy development.

- The role of the public and the form of its participation in the strategy development.

The real motives are usually different from public ones. As noted above, 21 local government officials were interviewed for this study, 2/3 of whom noted that the main motive for developing the strategy was «the external necessity». This includes the requirements of applications for grant / assistance from international beneficiaries of grants, the requirements of regional governance and the requirements of party leadership.

Thus, the identified and analysed factors allow us to assume that there is a situation where a large number of urban development strategies are established due to the need to meet the external requirements, the work is not public, and the public role and its participation in this work is not that essential. In this regard, after taking into consideration the basic level of distrust in the city authorities as well, it is quite logical to get a high level of criticism and a low level of support for any presented strategy.

Moreover, the criticism of the strategy unfolds from several stakeholder groups: the political parties that are in opposition to those who control the local government; the experts who are not included in the strategy development team; the nongovernmental organizations and activists who are dissatisfied with their role and the level of participation in the strategy development.

It is fairly obvious that the scale of criticism is many times greater than the potential of the city government taking into account the modern media opportunities.

The analysis of the scientific achievements of international researchers, together with our own study allow us to come to conclusion that this problem is inherent not only in Ukraine but actually in any country in the world as well. The reason for this is that it is based on the transformation processes, which are provoked by changes in the communication models and the rapidly growing media opportunities of individuals, groups and associations. Deloitte company notes this in its analysis of Government trends 2020. J. O'Leary and T. Murphy, the researchers of the company, propose a new approach to increase the effectiveness of mediation between authorities and stakeholders in the urban and territorial development, and the point is that «it is better for state and local governments to help citizens "do the right thing" in the first place than to go through the painful process of penalizing those who misbehave» (O'Leary, \& Murphy, 2021).

In summary of the first stage of our study, the authors believe that it is necessary to have a special technique aimed at overcome the problem of inhibitory factors and to increase the effectiveness of elaboration and implemention of 
urban and territorial development strategies and which can minimize the following factors:

- the low degree of public trust in the local authorities;

- the high degree of dependence of local government on political parties of the national level;

- the low degree of internal needs and motivation to create the development strategies.

In addition, it takes into consideration the following factors:

- the low communications capabilities level of most local governments;

- the high degree of society discretization on various grounds, such as language, income, the level of public consciousness, etc.;

- the low level of connection of political parties with the public sector;

- the high level of social tension and the long duration of the economic crisis in the country;

- a small number of modern professional managers, project managers in the local governments.

The second stage of our study is particularly devoted to the description of the developed TRuSt method, which is based on the projectscenario approach. Since 2014, the ReputationLab $^{\text {TM }}$ Research Centre has analysed the situation with the elaboration and implemention of urban and territorial development strategies in Ukraine as part of its own studies. One of the conclusions is the low level of communication during the development and presentation of strategies, that becomes one of the key factors of a high level of criticism, which in turn slows down the implementation of the strategy and mitigates / devalues the public assessment of its effectiveness (Hvylya, 2017).

The methodology of project-scenario approach, which is based on both the classical tools and the own laboratory developments, has been introduced in order to increase the efficiency of the development process and to improve the readiness for implementation.

The essence of the project-scenario approach is that the strategy is developed publicly, with a wide level of media coverage and the involvement of local experts and political parties. The development of the strategy is based on the existing potential of the city, the project ideas and their activists, while the external experts act as moderators who help the city management together with the city assets to refine these ideas to the level of real projects (business plans) through the use of methods of participation, modeling and mediation and to formulate a nuanced image of the future, which largely includes the images of the future key stakeholder groups. Moreover, the project ideas are comprehensively tested for the realistic implementation and the practical value in the process of formulating a strategy. At the next stage, the tested projects (including their implementation teams) are combined into the Development Strategy. The media program covering the process and the opinion surveys provide an interactive connection with the city community.

The Triad Retrospective Scripting (TRuSt) method was taken as a basis, the essence of which is that it forms an organic connection between the individual elements (subsystems) and the cohesion of different experts' visions into a holistic system of scenarios of transition from the current state to the planned (future) one. At the same time, the work begins with determining the image of the future (planned state) of the multifactor system, which generally meets the goals and aspirations of all stakeholder groups involved in the strategy development. Then the probable scenarios (orbits) of the movement of various subsystem factors are determined, which involve the consideration of the influence of the subsystems on each other and the creation of an interconnected action system (achieving results) (Kashpur, 2015).

Therefore, the technique provides:

- the manifestation of individual experts' subjective visions and their representation as an integral system of multifactor vision (helicopter view);

- building links between actions and their consequences (results) in different subsystems;

- the creation of step-by-step system transition scenarios from one state to another that are synchronized but not rigidly connected to the timeline.

This methodology was supplemented by sociological research and media program of work coverage, which provided the interactive communication (testing) of working versions of the strategy and its elements (projects) as well as significantly increased the number of experts and city residents who were informed and involved in its development. 


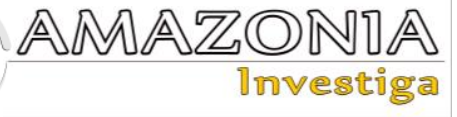

The methodology consists of several (usually 35) acts of work that have a similar architecture and that are built on such principle as collective vision - individual expert visions - collective vision of a new level.

Thus, each stage has the following architecture: a sociological and expert research, a modeling session, the work in the project groups, the presentation of the results of working groups and their public discussion, the transition to the next act.

The elaboration is completed by public presentation of the strategy, its subsystems and projects. The details are available in an operation algorithm of the Figure 1.

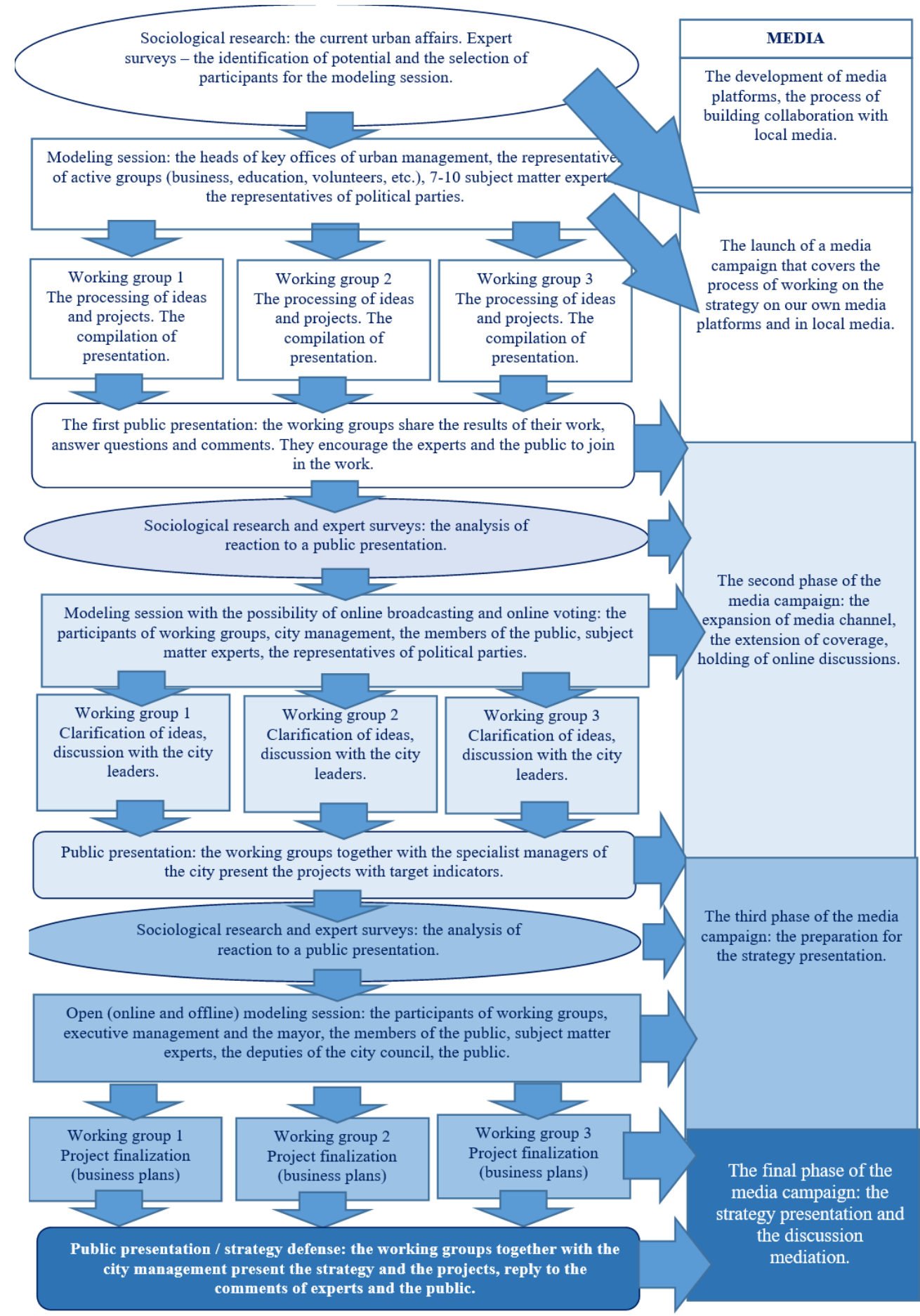

Figure 1. An algorithm for the application of TRuSt technique. Source: Authors' computation 
According to its authors, the advantages of this approach are:

- feasibility - the projects are based on the local staff, they have a clear financial model and a certain role in the urban development;

- resistance to criticism - the involvement of representatives of different pressure groups turns them into allies;

- media prominence - the coverage continues throughout the development and increases the public confidence in the proposed solutions and projects;

- flexibility - the system responds quickly to changes in the external and internal environment;

- $\quad$ publicity - the active communication with the public on their own information platforms and the systematic sociological research.

The combination of public and business assets of the city with the systematic experience of subject matter experts creates the space of realistic projects. The sociological research system synchronizes the project space with the urban residents' expectations. Own media platforms and media products maintain the interactive communication with the city residents and provide public support. A comprehensive scenario development strategy is built on this basis.

The third stage of the study is its practical testing. Consider a specific example of the method: December 2020 - February 2021, the city of Konotop (Sumy Region in Ukraine) with a population of 86,000 inhabitants (figure for the year 2019).

The input data: the city does not have the Development Strategy and the experience in its creation, the revenues of the city have decreased by 198 million hryvnias in 2020 compared to 2019 (from 729.3 million hryvnias to 531,3 million hryvnias) (Konotop city council, 2018), the low clarity level of the city authorities (Konotop city council, 2019), the absence of a coalition in the newly elected city council, the active opposition of various political groups in the media, the development takes place during the re-election of the mayor. Objective: to develop a framework for a strategic development plan, which will be supported by a significant number of experts and city residents, and that will allow to finalize it in the city council after the election for mayor (Transparency international group, 2021).
The strategy development customer: the local communications company within the framework of its own program to promote the urban development (corporate social responsibility).

The initial sociological research shows that more than $40 \%$ of Konotop residents are dissatisfied with the living conditions in their city, and about $30 \%$ of them believe that the life has deteriorated over the past two years. Furthermore, according to the sociological and expert surveys, the following current problems of urban life were identified, such as a lack of jobs, the poor condition of roads, the provision of amenities to the residential areas, the quality of medical care, the development of educational infrastructure and the quality of education, the development of cultural infrastructure, the welfare assistance of the most disadvantaged sections of the population (Social, Political \& Market Research, 2020).

The project on the urban development strategy began with a modeling session («Konotop Development Plan», December 12, 2020), which was attended by the invited subject matter experts, three candidates for mayor, the representatives of various political parties from the city council and more than 30 local activists who are representatives of public associations (Konotop Development Plan, 2020).

As the result of this session, five working groups responsible for the areas such as transport, social sphere, education, culture, infrastructure projects have been created. One of the candidates has also been selected as the public figure of the strategy development project.

More than 20 working group meetings were held to discuss and develop the project ideas during December 2020. A Facebook page Konotop Development Plan, a project website as an online mayor reception with the possibility of prompt submission of proposals for the improvement of the city (konotop.org.ua, 2020), the community of private and corporate pages of the project participants and the press service were created for media coverage of the work. The total media coverage of the first stage (December 2020) amounted to more than 0,5 million contacts and more than 100,000 video views. Three public organizations and several initiative groups have joined the working group.

At the end of the first act of work, that is early January 2021, the presentations of the first results of the working groups on medicine, education, housing and utilities infrastructure, social sphere, 


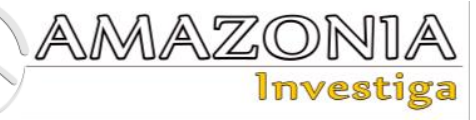

cultural development, young people's issues were shown. The total media coverage of the presentations amounted to about 1 million contacts and more than 200,000 video views. The response rate averaged $100-200$ reactions to one message, and less than $5 \%$ of them were negative.

The second act of the work began with sociological research which showed a high level of public support for the project by more than $85 \%$ of respondents, who knew about the beginning of the elaboration of urban development strategy, supported the idea and its participants. At the same time, about $40 \%$ of the city residents were unaware of the work on the strategy when the survey was conducted.

The results of expert research (interviews) also showed a fairly high level of support for the project to develop an urban strategy since the vast majority of interviewed experts and city council members expressed either willingness to join a particular working group or public support for the project.

Taking the above mentioned into consideration, the following conclusion can be drawn that more than 100 experts, the local government officials, the deputies in the Regional Council and Verkhovna Rada of Ukraine joined in the work on the strategy. The project was supported by four out of six political forces of the city council (a total of 19 deputies out of 38). The roadmap and the strategic vision of the city development directions were prepared and 23 project ideas were handled. Media coverage was about 2 million contacts. A separate website, an online mayor reception, a Facebook page, more than 20 video products, more than 100 text products (articles, posts on social networks, etc.) were created and two waves of sociological and expert research were conducted during the work.

According to the authors of the project and the authors of this study, the main result is the fact that the work on the strategy was continued, and much of the work was included in the agenda of the city council despite the victory of another candidate in the election for mayor.

From the scientific point of view, the considered technique and an example of its practical application contains the following scientific value:

- it confirms the assumption that the increase of the stakeholder group mediation effectiveness with different patterns of behavior and goals is one of the most pressing issues in both theoretical research and urban and territorial management practice within the context of the everyday world of dynamic growth of communications opportunities;

- $\quad$ it demonstrates the positive results of one of the possible approaches since a high level of public involvement in the development of strategies of various stakeholder groups minimizes the number and the intensity of negative feedback, even in the situation of steady growth of distrust in government;

- the considered TRuSt method develops the existing methods of social mediation and joint action moderation of different stakeholder groups within the framework of the modern open information space concept.

Regarding the scientific and practical value of this technique, the authors of the study consider that it is worth mentioning the following points of its completion and the opportunities for its development and improvement:

- it is necessary to have clearer explicitation and formalization of the final products and documents of both the strategy itself and its project components;

- further attention to the scientific and theoretical basis of the elements of the methodology, which were developed by its authors and their combination with those elements that are traditionally used in such work; - more detailed definition of the role and structure of expert and sociological research;

- wider range of practical testing: in other cities of Ukraine, other countries and outside the election situation;

- $\quad$ expansion of the application range from the urban level to the regional and territorial ones.

Based on the above and taking into account the recommendations, the authors of this study consider that it is appropriate to use this technique as a key or additional one in the process of developing urban and territorial strategies.

According to the authors of this study, the main advantages of the technique are:

- $\quad$ the clarity and the processability of both the elements and the technique in its entirety;

- the ability to scale it without losing integrity and efficiency;

- the high level of involvement of local experts, activists and the public; 
- $\quad$ the high mediation potential in building a common workspace of various stakeholder groups with different professional focuses and different vectors of vision of the goals and objectives of the urban and territorial development strategy;

- the high media potential, which contributes to the consolidation of public forces and the increase of confidence in local authorities, both in the field of application of the technique and at the level of the country in its entirety.

\section{Conclusions}

The authors of this study consider that the issue of elaboration of methods for involvement of all levels of experts and the public in elaborating urban and territorial development strategies in order to increase their effectiveness is relevant in scientific and practical activities of Ukraine and other countries where the process towards democracy is taking place. The results of the study confirm that the effective elaboration and implementation of development strategies in modern society require better understanding of the goals and the behaviour patterns of various stakeholder groups, including the public, and their more active involvement in the development of urban and territorial strategies.

Accordingly, the development and testing of methods that comprehensively apply the research tools, the mediation and the media produce promising results, forming a single project volume which has the following characteristics:

- involvement of representatives of the widest possible range of stakeholder groups;

- $\quad$ high level of media coverage;

- complexity of the research that provides fast and effective feedback.

As a result, it is possible to build a reflective project system capable of effectively develop the strategies with optimal consideration of the goals and requests of different stakeholder groups, but without losing the overall goal of such a strategy.

The methodology that has been studied is considered to be promising, especially considering the decentralization processes in Ukraine and the global processes of state and local government transformation.

The given example of practical approbation shows that the technique under investigation gives positive results especially in the aspect of consolidation of various stakeholder groups in collaborative work on the territorial development strategy, wider and deeper involvement of the public in this type of work and the minimization of destructive criticism.

The practical testing of the TRuSt method has shown that it allows to significantly reduce the level of negative feedback as well as to involve the stakeholder groups, that are in opposition to each other under other conditions, in collaborative work.

\section{Bibliographic references}

Active Group. (2020). Evaluation of the results of local elections. Retrieved february 5, 2021, from https://activegroup.com.ua/wpcontent/uploads/2020/12/201206_omnibus_ mist_vybory.pdf

Association of Ukrainian Cities. (2017). Final report on the results of public and expert opinion surveys. Retrieved July 5, 2021, from https://auc.org.ua/sites/default/files/library/a mu_2017_ua_mista_otg_new.pdf

Council of Europe (2020, September). Enhancing decentralisation and public administration reform in Ukraine Decentralization and local government reform. The results of the fifth wave of sociological research among the population of Ukraine. Retrieved July 5, 2021, from http://www.slg-coe.org.ua/wpcontent/uploads/2020/11/2020Report_UKR_ ukr_1.pdf

Dallabrida, V.R. (2015). Territory planning and management: the theory debate in Brazil and a prospect of practice according to theoretical contributions on territorial governance. Revista Brasileira de Gestão e Desenvolvimento Regional, 11(4), pp. 51-77. Retrieved July 5, 2021, from https://rbgdr.net/revista/index.php/rbgdr/arti cle/view/2031

Golikov, S., Korneyko, O., \& Krasova, E. (2018). The strategy of territory socioeconomic image formation. Amazonia Investiga, 7(15), pp. 262-270. Retrieved from

https://amazoniainvestiga.info/index.php/am azonia/article/view/456

Hvylya. (2017, 6 November). Ukraine in the world 2030. Retrieved 5 July 2021, from https://hvylya.net/analytics/society/ukrayinau-sviti-2030.html

Jouini, M., Burte, J., Biard, Y., Benaissa, N., Amara, H., and Sinfort, C. (2019). A framework for coupling a participatory approach and life cycle assessment for public decision-making in rural territory 


\section{AMAZONZA \\ 1กvestiำ}

management. Science of The Total Environment, 655, pp. 1017-1027. DOI: https://doi.org/10.1016/j.scitotenv.2018.11.2 69

Kashpur, A. (2015). Triad Retrospective Scripting (TRuSt). Reputation (pp. 7). Retrieved from https://reputationbook.org/triadretrospective-scripting/

Kolomoiets, T., Galitsina, N., Sharaia, A., Kachuriner, V., \& Danylenko, O. (2021). International experience of public-private partnership in agriculture. Amazonia Investiga, 10(41), pp. 160-168. DOI: https://doi.org/10.34069/AI/2021.41.05.16

Konotop city council. (2018, 21 December). About the city budget for 2019. Retrieved July 5, 2021, from https://konotop-rada.gov.ua/wpcontent/uploads/2018/11/Budget_2019.pdf

Konotop city council. (2019, 21 December). About the city budget for 2020. Retrieved July 5, 2021, from https://konotop-rada.gov.ua/wpcontent/uploads/2019/11/\%D0\%A0\%D1\%9 $6 \% \mathrm{D} 1 \% 88 \% \mathrm{D} 0 \% \mathrm{~B} 5 \% \mathrm{D} 0 \% \mathrm{BD} \% \mathrm{D} 0 \% \mathrm{BD} \%$ D1\%8F-1-1.pdf

Novikov, S., \& Veas Iniesta, D. (2019). Analysis of development trends in the innovation industry of the Russian Federation. Amazonia Investiga, 8(19), 298-307. Retrieved from https://amazoniainvestiga.info/index.php/am azonia/article/view/231

O'Leary, J., \& Murphy, T. (2021). How state and local governments can use nudge thinking to improve outcomes. Deloitte. Retrieved July 5, 2021, from https://www2.deloitte.com/za/en/insights/foc us/behavioral-economics/how-state-localgovernments-can-apply-nudge-thinking.html

Simone, C. \& Barile, S., \& Calabrese, M. (2018). Managing territory and its complexity: a decision-making model based on the viable system approach (VsA). Land Use Policy, 72, pp. 493-502. DOI: https://doi.org/10.1016/j.landusepol.2017.12. 070
Social, Political \& Market Research. (2020, December 19). Socio-political situation in Konotop city OTG in mid-December 2020. Retrieved July 5, 2021, from https://sociopolis.ua/images/Konotopska_O TG_12_2020.pdf

Stewart, J., \& Lithgow, Sh. (2015). Problems and prospects in community engagement in urban planning and decision-making: three case studies from the Australian Capital Territory. Policy Studies, 36, pp.18-34. DOI: https://doi.org/10.1080/01442872.2014.9810 61

Transparency international group. (2021, 31 March). Rankings of transparency and accountability-2020. Retrieved July 5, 2021, from https://wiki.nazk.gov.ua/wpcontent/uploads/2021/04/Analitychnyj-zvit.Rejtyngy-prozorosti-ta-pidzvitnosti-mist2020-1.pdf

Ugurchiev, O., Dovtaev, S.-A., Tochieva, L., Sabanchiev, A., \& Misakov, A. (2019). Essence and features of leading development territory creation taking into account global factors. Amazonia Investiga, 8(19), pp. 631-637. Retrieved from https://amazoniainvestiga.info/index.php/am azonia/article/view/278

Ustugova, S., Parygin, D., Sadovnikova, N., Finogeev, A., \& Kizim, A. (2016). Monitoring of Social Reactions to Support Decision Making on Issues of Urban Territory Management. Procedia Computer Science, 101, pp. 243-252. DOI: https://doi.org/10.1016/j.procs.2016.11.029

Vergara-Romero, A., \& Sorhegui-Ortega, R. (2020). Local development factors from the organizational management perspective. Amazonia Investiga, 9(33), pp. 46-50. DOI: https://doi.org/10.34069/AI/2020.33.09.5

Zavgorodny, S. (2020, Decmber 21). Konotop Development Plan. 1st session [Video]. YouTube.

https://www.youtube.com/watch?v=XpHm MPKUuug\&feature $=$ youtu.be 